\title{
PENGEMBANGAN PROGRAM PEMBELAJARAN KURIKULUM 2013 DI PAUD RAUDHATUL ALTHFAL MUSLIMAT DESA KUNGKAI BARU KABUPATEN SELUMA
}

\author{
DEVELOPMENT OF 2013 CURRICULUM LEARNING PROGRAM IN PAUD \\ RAUDHATUL ALTHFAL MUSLIMAT \\ NEW KUNGKAI VILLAGE SELUMA REGENCY
}

\author{
${ }^{1)}$ Nasirun, ${ }^{2)}$ Yulidesni, ${ }^{3)}$ Indrawati, ${ }^{4}$ Zahratul Qalbi \\ ${ }^{1-4}$ Fakultas Keguruan dan Ilmu Pendidikan, Universitas Bengkulu \\ *Email: zahratulqalbi@unib.ac.id
}

\begin{abstract}
ABSTRAK
Tujuan melakukan kegiatan pengabdian yaitu untuk meningkatkan kemampuan guru dalam pengembangan program pembelajaran paud kurikulum Paud (Program Tahunan, Smester dan Program Harian) di Paud Raudhatul Althfal Muslimat Desa Kungkai Baru Kec. Air Periukan Kab. Seluma. Pemecahan masalah dalam kegiatan pengabdian pada masyarakat ini dilakukan dengan pemberian konsep berkaitan kurikulum dan program pembelajaran serta pelatihan pengembangan program pembelajaran anak usia dini dengan kurikulum 2013 (Program Tahunan, Smester dan Program Harian) di Paud Raudhatul Althfal Muslimat Desa Kungkai Baru Kec. Air Periukan Kab. Seluma. Khalayak sasaran dalam kegiatan pengabdian pada masyarakat ini adalah seluruh guru berjumlah 17 orang guru di Paud Raudhatul Althfal Muslimat Desa Kungkai Baru Kec. Air Periukan Kab. Seluma. Setelah dilaksanakan kegiatan pengabdian pada masyarakat yang berupa pengembangan program pembelajaran paud kurikulum dan setelah dilakukan penilaian berupa umpan balik dari peserta dapat disimpulkan bahwa kegiatan pengabdian dapat berjalan dengan baik dan dirasa sangat bermanfaat bagi guru, sesuai dengan harapan dan tujuan kegiatan pengabdian pada masyarakat ini. Kegiatan pengabdian pada masyarakat tersebut sangat baik dan bermanfaat bagi para guru sebab membantu guru dalam memecahkan masalah yang dihadapi berupa pemahaman kurikulum dan program pembelajaran anak usia dini pada Paud Raudhatul Althfal Muslimat Desa Kungkai Baru Kec. Air Periukan Kab. Seluma.
\end{abstract}

Kata kunci: Kurikulum 2013, Program Pembelajaran, Paud

\section{ABSTRACT}

The purpose of conducting service activities is to improve the ability of teachers in developing early childhood curriculum learning programs (Annual Programs, Semesters and Daily Programs) at Raudhatul Althfal Muslimat Early Childhood Education in Kungkai Baru Village, Kec. Fishery Water District. Kab. seluma. Problem solving in community service activities is carried out by providing concepts related to curriculum and learning programs as well as training in the development of early childhood learning programs with the 2013 curriculum (Annual Program, Semester and Daily Program) at Raudhatul Althfal Muslimat Paud Desa Kungkai Baru Kec. Fishery Water District. Kab.Seluma. The target audience in this community service activity are all 17 teachers at Raudhatul Althfal Muslimat Paud, Kungkai Baru Village, Kec. Fishery Water District. so long. After carrying out community service activities in the form of developing early childhood curriculum learning programs and after conducting an assessment in the form of feedback from participants, it can be concluded that service activities can run well and are considered very useful for teachers, in accordance with the expectations and objectives of this community service activity. The community service activity is very good and useful for teachers because it helps teachers in solving problems they face in the form of understanding the curriculum and early childhood learning programs at Raudhatul Althfal Muslimat Paud in Kungkai Baru Village, Kec. Fishery Water District. Kab. Seluma

Keywords: Curriculum 2013, Learning Program, Early Childhood Education

Diterima: 21-06-2021 Disetujui: 23-06-2021 Dipublikasikan: 30-06-2021 


\section{PENDAHULUAN}

Pendidikan Anak Usia Dini (PAUD) merupakan proses pendidikan yang sangat fundamental dan sangat penting sebab pada proses pendidikan tersebut untuk meletakkan dasar (pemberian rangsangan dan stimulan) yang dapat menentukan masa depan anak. Pada masa tersebut, merupakan masa "golden age" dan "risk age" yang menentukan masa depan anak. Oleh karena itu, penyelenggaraan pendidikan pada PAUD harus dapat memberikan kesempatan tumbuh kembang anak secara optimal melalui kurikulum yang darancang dengan baik. Oleh karena itu, kurikulum yang darancang dengan baik akan pembawa proses pembelaharan dengan baik dan guru mudah melaksanakan kurikulum tersebut.

Kurikulum merupakan pemandu guru untuk memenuhi seluruh area belajar yang digunakan anak dengan memakai pendekatan pembelajaran yang tepat, strategi penataan lingkungan yang sesuai untuk mendukung berkembangnya kualitas kemampuan anak sesuai dengan tahap perkembangannya.

Kurikulum merupakan salah satu unsur yang memberikan kontribusi untuk mewujudkan proses berkembangnya kualitas potensi anak didik.Kurikulum 2013 PAUD dikembangkan berbasis pada kompetensi sangat diperlukan sebagai instrumen untuk mengarahkan anak didik menjadi: (1) Manusia berkualitas yang mampu dan proaktif menjawab tantangan zaman yang selalu berubah; (2) Manusia terdidik yang beriman dan bertakwa kepada Tuhan Yang Maha Esa, berakhlak mulia, sehat, berilmu, cakap, kreatif, mandiri; dan (3) Warga negara yang demokratis, bertanggung jawab (Materi Paedagogik, Diknas Dirjen GTK; 2017;2).

Undang-Undang Nomor 20 Tahun 2003 tentang Sistem Pendidikan Nasional menyebutkan bahwa kurikulum adalah seperangkat rencana dan pengaturan mengenai tujuan, isi, dan bahan/materi pembelajaran, serta cara yang digunakan sebagai pedoman penyelenggaraan kegiatan pembelajaran untuk mencapai tujuan pendidikan tertentu. Berdasarkan pengertian tersebut, terdapat dua dimensi kurikulum. Dimensi; 1) pertama adalah rencana dan pengaturan mengenai tujuan, isi, dan bahan pelajaran, sedangkan yang 2) kedua adalah cara yang digunakan untuk kegiatan pembelajaran (Materi Paedagogik, Diknas Dirjen GTK; 2017;2-3).

Guru sebagai pelaksana proses pembelajaran (kegiatan proses belajar mengajar) di kelas (pengertian kurikulum dimensi kedua), dituntut untuk dapat melakukan persiapan dengan baik khususnya dalam penyusunan program pembelajaran berupa: pemahaman kurikulum, penyusunan program pembelajaran (tahunan, semester, mingguan dan harian). Program pembelajaran yang disusun dengan baik akan membuat proses pelaksanaan pembelajaran juga baik, diharapkan hasil belajar anak menjadi baik dan optimal.

Dalam penyusunan program pembelajaran hendaknya guru harus memahami isi kurikulum khususnya kurikulum 2013. Dalam struktur kurikulum 2013 terdiri dari kompetensi inti (KI), kompetensi dasar (KD) dan standar tingkat pencapaian perkembangan anak (STPPA), tema-subtema, dan struktur KI dan KD dan kaitannya dengan aspek perkembangan.

Pada kenyataan di lapangan (khususnya di PAUD Raudhatul Althfal Muslimat Desa Kungkai Baru Kec. Air Periukan Kab. Seluma) guru belum memahami kurikulum 2013 dan program pembelajaran (program tahunan, semester, migguan dan harian). Hal tersebut disebebkan PAUD Raudhatul Althfal Muslimat Desa Kungkai Baru Kec. Air Periukan Kab. Seluma berada dilingkungan Departemen Agama (Depag), sehingga para guru belum benar-benar memahami kurikulum 2013 dan program pembelajaran 
yang menyertainya berada di bawah pendidikan nasional (Diknas).

Tugas guru dalam kaitannya dengan penyusunan program pembelajaran diantaranya: 1) Pemahaman terhadap kurikulum 2013; 2) penyusunan program tahunan; 3) penyusunan program semester; 4) penyusunan program mingguan (RPPM); 5) penyusunan program harian (RPPH).

Kurikulum 2013 PAUD diberlaku kan berdasarkan Peraturan Menteri Pendidikan dan Kebudayaan Nomor 146 tahun 2014 tentang kurikulum Pendidikan Anak Usia Dini (PAUD). Kurikulum 2013 PAUD berlaku pada kelompok A dan kelompok B di PAUD Negeri maupun Swasta yang berada dalam departemen pendidikan nasional (Diknas). Namun demikian, Raudhathul Athfal (RA) juga menggunakan kurikulum tersebut dengan penambahan Pendidikan Agama Islam (PAI). Oleh karena itu, perlu adanya sosialisasi kurikulum 2013 PAUD pada lembaga RA tersebut, untuk memahamkan apa saja yang terkandung dalam kurikulum 2013 PAUD tersebut.

Program tahunan dan program semester merupakan tahap pertama dalam penyusunan program pembelajaran yang harus dilakukan oleh guru. Program tahunan dan program semester sebagai landasan atau dasar bagi guru untuk dapat menyusun program-program pembelajaran berikut, seperti program mingguan dan program harian.

$$
\begin{gathered}
\text { Komponen dalam program tahunan } \\
\text { dan program semester diantaranya: }
\end{gathered}
$$
Kompetensi Inti (KI); Kompetensi Dasar (KD); Tema dan sub-tema; Materi; Waktu; Alat dan sumber; dan Penilaian. Program mingguan merupakan penjabaran dari program semester dan sebagai dasar dalam penyusunan program harian. Bila program mingguan baik diharapkan program harian menjadi jelas dan baik. Oleh karena itu, kemampuan guru dalam menyusun program mingguan menjadi penting bagi guru sebab akan menentukan sukses dan tidaknya pelaksanaan pembelajaran di kelas. Komponen dalam program mingguan terdiri: Kompetensi Inti (KI); Kompetensi Dasar (KD); Tema dan sub-tema; Materi Pembelajaran; Rencana Kegiatan; Waktu; Alat dan sumber; dan Penilaian.

Program penyusunan harian (Rencana Pelaksanaan Pembelajaran) merupakan hal penting dalam proses pembelajaran, sebab rencana pelaksanaan pembelajaran merupakan pedoman dan pengarah bagi guru. Hasil proses pembelajaran menjadi optimal jika perencanaan pembelajaran baik. Komponen dalam program harian terdiri: Kompetensi Inti (KI); Kompetensi Dasar (KD); Tema dan sub-tema; Materi Pembelajaran; Rencana Kegiatan (Kegiatan Pendahuluan, Kegiatan Inti dan Kegiatan Penutup; Waktu; Alat dan sumber; LKPD dan Kriteria dan kunci Penilaian.

Permasalahan yang muncul di lapangan masih banyak para guru PAUD yang belum memiliki kemampuan dalam pengembangan program pembelajaran tahunan, semester, mingguan dan harian (RPPM dan RPPH). Oleh karena itu, melalui kegiatan pengabdian pada masyarakat ini akan membantu pemecahan masalah yang dihadapi guru, sekaligus dapat membantu guru dalam meningkatkan kemampuannya dalam pengembangan program pembelajaran tahunan, semester, mingguan dan harian (RPPM dan RPPH) di PAUD Raudhatul Althfal Muslimat Desa Kungkai Baru Kec. Air Periukan Kab. Seluma.

Kurikulum merupakan pedoman dan petunjuk arah bagi guru yang akan melaksanakan proses pembelajaran baik dalam kelas maupun diluar kelas. Kurikulum juga sangat menentukan tercapai tidaknya capaian tujuan pembelajaran yang telah ditetapkan. Demikian pentingnya posisi kurikulum, hendaknya para guru harus memahami dan menerapkan dalam perencanaan program pembelajaran. Menurut Undang-undang RI Nomor: 20 Tahun 2003 tentang Sistem Pendidikan 
Nasional disebutkan: Kurikulum adalah seperangkat rencana dan pengaturan mengenai tujuan, isi, dan bahan pelajaran serta cara yang digunakan sebagai pedoman penyelenggaraan kegiatan pemelajaran untuk mencapai tujuan pendidikan tertentu. Menurut Hamalik dalam Wiryokusumo (1998;2-3), Kurikulum adalah sejumlah mata pelajaran yang harus ditempuh oleh murid untukmemperoleh ijasah. Pengertian kurikulum di atas berlaku pada lembaga pendidikan yang menggunakan mata pelajaran, sementara di lembaga PAUD tidak menggunakan mata pelajaran tetapi aspek-aspek perkembangan yang harus distimulasi sehingga dapat berkembang secara optimal. Menurut Alberty (1965) dalam Hernawan dan Cynthia (2011;2) menyebutkan bahwa kurikulum sebagai semua kegiatan yang diberikan kepada siswa dibawah tanggugjawab sekolah (all of the activities that are provided for the students by the school). Sehingga kurikulum tidak dibatasi pada kegiatan di dalam kelas, tetapi mencakup juga kegiatan-kegiatan yang dilakukan siswa di luar kelas. Sejalan pendapat di atas, Saylor, Alexander, dan Lewis (1974) dalam Hernawan dan Cynthia (2011;2), kurikulum sebagai segala upaya sekolah untuk mempengaruhi siswa supaya belajar, baik dalam ruangan kelas, di halaman sekolah maupun di luar sekolah. Menurut Ibrahim (2005) dalam Hernawan dan Cynthia (2011;5) mengelompokkan kurikulum menjadi tiga dimensi, yaitu:dimensi sebagai substans, kurikulum sebagai sistem dan kurikulum sebagai bidang studi. Dimensi pertama kurikulum sebagai rencana kegiatan belajar bagi siswa di sekolah atau sebagai perangkat tujuan yang akan dicapai. Menurut Suminah, dkk. $(2015 ; 4)$ Kurikulum sebagai inti yang menggerakkan dan mengarahkan proses pendidikan (proses pembelajaran), sehingga kurikulum harus dapat mengembangkan potensi peserta didik menjadi kemampuankemampuan yang diperlukan dalam kelanjutan pendidikan dan kehidupannya. Kurikulum harus menyiapkan anak untuk masa depan bukan hanya untuk masa kini.

Berdasarkan uraian tersebut, kurikulum yang diperlukan untuk mencapai proses pembelajaran agar berhasil secara optimal adalah kurikulum yang memenuhi kebutuhan lembaga pendidikanya. Demikian juga kurikulum yang berlaku pada lembaga pendidikan PAUD harus dapat menyiapkan anak usia dini (AUD) pada kesiapan belajar anak (KBA) sebagaimana tercantum dalam Undang-undang Sistem Pendidikan Naional Bab. I; pasal 1 butir 14 tentang pengertian PAUD.

Rumusan masalah dalam kegiatan pengabdian pada masyarakat ini adalah: Bagaimana meningkatkan kemampuan guru dalam pengembangan program pembelajaran paud kurikulum PAUD (Program Tahunan, Smester dan Program Harian) DI PAUD Raudhatul Althfal Muslimat Desa Kungkai Baru Kec. Air Periukan Kab. Seluma?

Tujuan yang diharapkan dan akan dicapai dalam kegiatan pengabdian pada masyarakat ini adalah: Meningkatkan kemampuan guru dalam pengembangan program pembelajaran paud kurikulum PAUD (Program Tahunan, Smester dan Program Harian) DI PAUD Raudhatul Althfal Muslimat Desa Kungkai Baru Kec. Air Periukan Kab. Seluma.

Pemecahan masalah dalam kegiatan pengabdian pada masyarakat ini dilakukan dengan pemberian konsep berkaitan kurikulum dan program pembelajaran serta pelatihan pengembangan program pembelajaran anak usia dini dengan kurikulum 2013 PAUD (Program Tahunan, Smester dan Program Harian) DI PAUD Raudhatul Althfal Muslimat Desa Kungkai Baru Kec. Air Periukan Kab. Seluma. 


\section{METODE}

Metode kegiatan yang akan dilakukan dalam kegiatan pengabdian pada masyarakat ini adalah ceramah berkaitan konsep kurikulum dan program pembelajaran, tanya jawab berkaitan konsep kurikulum dan program pembelajaran, penugasan atau latihan tentang Pengembangan program pembelajaran anak usia dini dan kurikulum 2013 PAUD (Program Tahunan, Smester dan Program Harian) DI PAUD Raudhatul Althfal Muslimat Desa Kungkai Baru Kec. Air Periukan Kab. Seluma.

Khalayak sasaran dalam kegiatan pengabdian pada masyarakat ini adalah seluruh guru berjumlah 17 orang guru di PAUD Raudhatul Althfal Muslimat Desa Kungkai Baru Kec. Air Periukan Kab. Seluma.

\section{HASIL DAN PEMBAHASAN}

Kegiatan orientasi. Kegiatan pengabdian pada masyarakat ini diawali kegiatan orientasi.

Kegiatan orientasi diisi pemberian konsep-konsep kurikulum dan program pembelajaran (Program Tahunan, Smester dan Program Harian). Kegiatan orietntasi selain diisi dengan penyampaian materi atau konsep-konsep tentang kurikulum dan program pembelajaran (Program Tahunan, Smester dan Program Harian), juga ditambah dengan tanya-jawab dan diskusi seputar materi. Pengebangan program pembelajaran meliputi: penyampaian materi kurikulum 2013 PAUD; program-program pembelajaran yang meliputi: program tahunan (prota), program semester (prosmes), program mingguan (RPPM) dan program harian (RPPH).
Kesimpulan dari kegiatan orientasi ini, masih perlu memberikan materi-materi berkaitan dengan kurikulum dan pengembangan program pembelajaran anak usia dini meliputi: kurikulum PAUD (Program Tahunan, Smester dan Program Harian) DI PAUD Raudhatul Althfal Muslimat Desa Kungkai Baru Kec. Air Periukan Kab. Seluma;

Setelah dilaksanakan kegiatan orientasi dengan materi (terlampir), selanjutnya dilaksanakan pelatihan (workshop) pengembangan program pembelajaran paud kurikulum PAUD (Program Tahunan, Smester dan Program Harian) DI PAUD Raudhatul Althfal Muslimat Desa Kungkai Baru Kec. Air Periukan Kab. Seluma. Penyusunan program harian (Rencana Program Pembelajaran Harian) dilaksanakan dengan tugas yang dikerjakan dalam waktu satu bulan di tempat kerjanya.

Dari pelaksaan kegiatan pengabdian pada masyarakat ini dapat ditemukan beberapa peningkatan pemahaman guru tentang: (a) Kurikulum 2013 PAUD (b) Program pembelajaran (Program Tahunan; Program Semester; Program Mingguan dan Program Harian); (c) Tugas latihan penyusunan program pembelajaran (khususnya program harian). Untuk itu, diperlukan penjelasan-penjelasan mengenai konsep yang berkaitan dengan (a) Pemahaman para guru terhadap kurikulum 2013 PAUD dan program pembelajaran anak usia dini; (b) program tahunan; program semester; program mingguan dan program harian. 
Sebagai kesimpulan masih perlu peningkatan bagi guru terhadap: (a) Pemahaman para guru terhadap kurikulum 2013 PAUD; (b) program pembelajaran; dan (c) penyusunan program harian (RPPH).

Kurikulum 2013 PAUD; Undang Undang Nomor 20 Tahun 2003 tentang Sistem Pendidikan Nasional Bab I Pasal 1 butir 14 menyatakan bahwa PAUD merupakan suatu upaya pembinaan yang ditujukan kepada anak sejak lahir sampai dengan usia 6 tahun yang dilakukan melalui rangsangan pendidikan untuk membantu pertumbuhan dan perkembangan jasmani dan rohani agar anak memiliki kesiapan belajar dalam memasuki pendidikan lebih lanjut.

Kurikulum 2013 PAUD dirancang dengan karakteristik sebagai berikut: (a). Mengoptimalkan perkembangan anak yang meliputi: aspek nilai agama dan moral, fisikmotorik, kognitif, bahasa, sosial-emosional, dan seni yang tercermin dalam keseimbangan kompetensi sikap, pengetahuan, dan keterampilan; (b). Menggunakan pembelajaran tematik dengan pendekatan saintifik dalam pemberian rangsangan pendidikan; (c). Menggunakan penilaian autentik dalam memantau perkembangan anak; dan (d). Memberdayakan peran orang tua dalam proses pembelajaran (Materi PLPG Paedagogik, 2017).

Program Pembelajaran di PAUD; Pembelajaran diartikan sebagai proses interaktif antara guru dan siswa yang berlangsung secara dinamis. Pembelajaran menurut Degeng (1989) dalam Asyhar $(2012 ; 7)$ dimaksudkan sebagai upaya membelajarkan pembelajar (anak, siswa, peserta didik). Menurut Punaji dan Sihkabudin, 2005) Pembelajaran juga dimaksudkan sebagai upaya yang dilakukan oleh pembelajar (guru, instruktur) dengan tujuan untuk membantu siswa agar bisa belajar dengan mudah (Asyhar; 2012;7).

Menurut Hartati (2007, 44-46), pembelajaran pada pendidikan anak usia dini menganut prinsip berangkat dari yang dimiliki anak; belajar harus menantang pemahaman anak; dan belajar dilakukan sambil bermain. Belajar pada pendidikan Anak usia dini bukan datang dari orangorang disekitarnya (didekte) tetapi dimulai dari apa yang dimiliki anak itu sendiri. Belajar harus membuat anak untuk selalu mencoba dan berusaha untuk bisa melakukannya (menantang). Belajar dilakukan anak melalui berbagai permainan yang dilakukan oleh anak.

Prinsip-prinsip pembelajaran anak usia dini, diantaranya: (1). Pembelajaran berorientasi pada anak; (2). Pembelajaran sesuai perkembangan anak; (3). Pembelajaran sesuai keunikan setiap individu; (4). Pembelajaran belajar melalui bermain; (5). Anak belajar (konkrit menuju abstrak, sederhana menuju kompleks, gerakan menuju verbal, diri sendiri menuju sosial); (6). Anak pembelajar aktif; (7). Anak belajar dari interaksi sosial; (8). Lingkungan yang mendukung proses belajar; (9). Pembelajaran merangsang munculnya kreativitas dan inovatif; (10). Pembelajaran mengembangkan kecakapan hidup anak; (11). Pembelajaran mengembangkan berbagai sumber dan media yang ada di lingkungan sekitar; (12). Anak belajar sesuai dengan kondisi sosial budayanya; (13). melibatkan peran orang tua serta dan pendidik PAUD; (14). Simulasi pendidikan menyangkut semua aspek perkembangan.

$$
\text { Pengorganisasian kegiatan }
$$

pembelajaran di Taman Kanak-kanak dapat berupa: (1) kegiatan dilaksanakan di 
dalam/di luar kelas; (2) kegiatan dilaksanakan dalam suasana yang menyenangkan; (3) pengelolaan pembelajaran dilaksanakan secara individu, kelompok kecil dan besar; dan (4) kegiatan pokok meliputi: pembukaan, inti dan penutup.

Rencana Pelaksanaan Pembelajaran (RPPH) di PAUD. Guru dalam melaksanakan tugas pembelajaran dapat dibagi dalam tiga tahap, yaitu: (1) tahap perencanaan yaitu tahap sebelum pelaksanaan pembelajaran; (2) tahap pelaksanaan (pendahuluan; inti; dan penutup); tahap evaluasi dilaksanakan setelah pelaksanaan pembelajaran. Pada tahap perencanaan, guru harus menyusun atau membuat rencana pelaksanaan pembelajaran (RPP), sebagai pedoman dalam mengajar. Rencana Pelaksanaan Pembelajaran (RPP) adalah rencana kegiatan pembelajaran tatap muka untuk satu pertemuan atau lebih. RPP dikembangkan dari silabus untuk mengarahkan kegiatan pembelajaran peserta didik dalam upaya mencapai Kompetensi Dasar (KD). Setiap pendidik pada satuan pendidikan berkewajiban menyusun RPP secara lengkap dan sistematis agar pembelajaran berlangsung secara interaktif, inspiratif, menyenangkan, menantang, efisien, memotivasi peserta didik untuk berpartisipasi aktif, serta memberikan ruang yang cukup bagi prakarsa, kreativitas, dan kemandirian sesuai dengan bakat, minat, dan perkembangan fisik serta psikologis peserta didik.

Menurut Permendikbud 22 tahun 2016 tentang Standar Proses Pendidikan Dasar dan Menengah, ada beberapa prinsip dalam penyusunan Rencana Pelaksanaan
Pembelajaran (RPPH), diantaranya: (1). Perbedaan individual peserta didik antara lain kemampuan awal, tingkat intelektual, bakat, potensi, minat, motivasi belajar, kemampuan sosial, emosi, gaya belajar, kebutuhan khusus, kecepatan belajar, latar belakang budaya, norma, nilai, dan/atau lingkungan peserta didik; (2). Partisipasi aktif peserta didik; (3) Berpusat pada peserta didik untuk mendorong semangat belajar, motivasi, minat, kreativitas, inisiatif, inspirasi, inovasi dan kemandirian; (4). Pengembangan budaya membaca dan menulis yang dirancang untuk mengembangkan kegemaran membaca, pemahaman beragam bacaan, dan berekspresi dalam berbagai bentuk tulisan; (5) Pemberian umpan balik dan tindak lanjut RPP memuat rancangan program pemberian umpan balik positif, penguatan, pengayaan, dan remedi; (6) Penekanan pada keterkaitan dan keterpaduan antara KD, materi pembelajaran, kegiatan pembelajaran, indicator pencapaian kompetensi, penilaian, dan sumber belajar dalam satu keutuhan pengalaman belajar; (7) Mengakomodasi pembelajaran tematik-terpadu, keterpaduan lintas mata pelajaran, lintas aspek belajar, dan keragaman budaya; (8) Penerapan teknologi informasi dan komunikasi secara terintegrasi, sistematis, dan efektif sesuai dengan situasi dan kondisi.

Jadi seorang guru dalam menyusun rencana pelaksanaan pembelajaran (RPP) harus memperhatikan prinsip-prinsip tersebut, agar dalam penyusunan RPP tersebut sesuai dengan tujuan pembelajaran yang akan dicapai. Selain itu, selain memperhatikan prinsip-prinsip penyusunan RPP tersebut, guru harus memperhatikan komponen-komponen dalam rencana 
pelaksanaan pembelajaran (RPP). Sebagaimana disebutkan dalam Permendikbud 22 tahun 2016 tentang Standar Proses Pendidikan Dasar dan Menengah, ada 13 komponen dalam penyusunan Rencana Pelaksanaan Pembelajaran (RPP), terdiri atas: (1). Identitas sekolah yaitu nama satuan pendidikan; (2) Identitas mata pelajaran atau tema/subtema; (3) Kelas/semester; (4) Materi pokok; (5) Alokasi waktu ditentukan sesuai dengan keperluan untuk pencapaian KD dan beban belajar dengan mempertimbangkan jumlah jam pelajaran yang tersedia dalam silabus dan KD yang harus dicapai; (6) Tujuan pembelajaran yang dirumuskan berdasarkan KD, dengan menggunakan kata kerja operasional yang dapat diamati dan diukur, yang mencakup sikap, pengetahuan, dan keterampilan; (7) Kompetensi dasar dan indikator pencapaian kompetensi; (8) Materi pembelajaran, memuat fakta, konsep, prinsip, dan prosedur yang relevan, dan ditulis dalam bentuk butirbutir sesuai dengan rumusan indikator ketercapaian kompetensi; (9) Metode pembelajaran, digunakan oleh pendidik untuk mewujudkan suasana belajar dan proses pembelajaran agar peserta didik mencapai KD yang disesuaikan dengan karakteristik peserta didik dan KD yang akan dicapai; (10) Media pembelajaran, berupa alat bantu proses pembelajaran untuk menyampaikan materi pelajaran; (11) Sumber belajar, dapat berupa buku, media cetak dan elektronik, alam sekitar, atau sumber belajar lain yang relevan; (12) Langkah-langkah pembelajaran dilakukan melalui tahapan pendahuluan, inti, dan penutup; dan (13) Penilaian hasil pembelajaran.
Dari penjelasan tersebut, diharapkan guru dapat menyusun rencana pelaksanaan pembelajaran (RPP) sesuai yang diharapkan dan dapat mencapai proses pembelajaran yang maksimal, serta hasil pembelajaran yang optimal.

\section{SIMPULAN}

Setelah dilaksanakan kegiatan pengabdian pada masyarakat yang berupa pengembangan program pembelajaran paud kurikulum PAUD (Program Tahunan, Smester dan Program Harian) DI PAUD Raudhatul Althfal Muslimat Desa Kungkai Baru Kec. Air Periukan Kab. Seluma, dan setelah dilakukan penilaian berupa umpan balik dari peserta dapat disimpulkan bahwa kegiatan pengabdian pada masyarakat dapat berjalan dengan baik dan dirasa sangat bermanfaat bagi guru, sesuai dengan harapan dan tujuan kegiatan pengabdian pada masyarakat ini.

Saran; Berdasarkan hasil kegiatan dan masukan melalui angket yang diberikan kepada para guru tentang pengembangan program pembelajaran paud kurikulum PAUD (Program Tahunan, Smester dan Program Harian) DI PAUD Raudhatul Althfal Muslimat Desa Kungkai Baru Kec. Air Periukan Kab. Seluma, disarankan: Kegiatan pengabdian pada masyarakat tersebut sangat baik dan bermanfaat bagi para guru sebab membantu guru dalam memecahkan masalah yang dihadapi berupa pemahaman kurikulum dan program pembelajaran anak usia dini pada PAUD Raudhatul Althfal Muslimat Desa Kungkai Baru Kec. Air Periukan Kab. Seluma. Selain itu, kegiatan pelatihan semacam hendaknya dilakukan dalam rangka kerjasama sekolah dengan perguruan tinggi. 
DAFTAR PUSTAKA

Hartati, Sofia; (2009); How To Be a Good Teacher and To Be a Good Mother; Enno Media; Jakarta.

Hernawan, Asep Herry; dan Cynthia, Riche (2011); Pengertian, Dimensi, Fungsi dan Peranan Kurikulum; Tim Pengembang MKDK Kurikulum dan Pembelajaran FIP-UPI Rajawali Pers, Jakarta

Kemdikbud, Dirjen PAUD dan Pendidikan Masyarakat, Dir. PAUD (2015): Pedoman Kurikulum Pendidikan Anak Usia Dini 2013 Jakarta.

----------- (2015): Kurikulum Pendidikan Anak Usia Dini;Apa,Mengapa, dan Bagaimana Jakarta

Masitoh; Ocih Setiasih dan Hani Djoehaeni; (2005); Pendekatan Belajar Aktif di Taman Kanak-Kanak; Depdiknas, Jakarta.

Moeslichatun, R.; (2004); Metode Pengajaran di Taman Kanak-Kanak; Rineka Cipta, Jakarta.

Nasirun,M dan Yulidesni (2013), Peningkatan kompetensi profesional guru paud (pra-jabat an) melalui aplikasi pendekatan pembelajaran inovatif dalam mata kuliah strategi pembelajaran BCCT pada mahasiswa PAUD FKIP UNIB.

Peraturan Pemerintah No.19. Tahun 2005; tentang Standar Nasional Pendidikan, Jakarta.

Permendikbud Nomor 22 Tahun 2016 Tentang Standar Proses Pendidikan Dasar dan Menengah, Jakarta

--------- Nomor: 137 Tahun 2014; Tentang Standar Nasional Pendidikan Anak Usia Dini, Jakarta

--------- Nomor: 146 Tahun 2014; Tentang Kurikulum 2013 Pendidikan Anak Usia Dini, Jakarta

Suyanto, Slamet; (2005); Pembelajaran Untuk Anak TK; Depdiknas, Jakarta.

Wiryokusumo, Iskandar dan Mulyadi, Usman (1998); Dasar-dasar
Pengembangan Kurikulum; Bina Aksara;Jakarta 